\title{
Het gebruik van Oud en Nieuw Oost-Indiën van François Valentyn door bewindhebbers van de VOC in de achttiende eeuw
}

\begin{abstract}
This article discusses the circulation of information extracted from François Valentyn's Oud en Nieuw Oost-Indiën (1724-1726) during the eighteenth century, both with regards to the central organs of the Dutch East India Company (VOC) in the Netherlands and the VOC establishments in the East Indies. First, three documents are analysed that were part of five VOC directors' personal archives, with the aim to determine the way these directors made use of Valentyn's book. It is concluded that for these directors Oud en Nieuw Oost-Indiën was probably the most important source of information about the VOC's trading empire, while at the same time their epistemic interest was limited to matters of trade. Second, the usage of Valentyn's book in various VOC establishments in the East Indies is assessed on the basis of correspondence between these establishments with the VOC central government in Batavia. Because of the fact that Oud en Nieuw Oost-Indiën was used simultaneously as a source of information by several actors, both in the Netherlands and in the East Indies, this might have resulted in standardising the operational knowledge of the East Indies within the VOC network.
\end{abstract}

Keywords: François Valentyn, Oud en Nieuw Oost-Indiën, VOC, paper tools, standardisation of knowledge.

\section{Inleiding}

Oud en Nieuw Oost-Indiën (1724-1726) van dominee François Valentyn (16661727) was in de achttiende eeuw het enige werk waarin een omvattende voorstelling werd gegeven van het handelsimperium van de Verenigde Oostindische Compagnie (VOC). Valentyn had een grote hoeveelheid teksten, kaarten en afbeeldingen verzameld van gebieden waarover de VOC de souvereine machthebber was, die tot haar invloedsfeer behoorden of waarmee ze handel dreef, en er zijn eigen opmerkingen aan toegevoegd. Van deze gebieden gaf Valentyn in 
zijn werk "nauwkeurige beschrijvingen" van uiteenlopende lengte die de lezer een indruk moesten verschaffen van de geografie, bevolking, natuur, geschiedenis en godsdienst van een gebied. Alles bij elkaar bevatte zijn werk meer dan 5000 foliobladzijden met meer dan 1000 kaarten en afbeeldingen, verdeeld over vijf dikke boekbanden. Het geheel bood aan achttiende-eeuwse lezers het beste overzicht van de ver uiteen gelegen en cultureel zeer diverse gebieden die tot het handelsterrein van de VOC behoorden, van Kaap de Goede Hoop tot Japan. Het werk was overigens maar voor een klein deel gebaseerd op de ervaringen van de auteur. Onderweg naar de Indonesische archipel en op de terugweg naar Nederland had Valentyn Kaap de Goede Hoop vier keer bezocht. In de Indonesische archipel was hij lange tijd als predikant werkzaam geweest op Ambon (1686-1694, 1707-1712) en tussentijds negen maanden op Banda (1687-1688). Ook Batavia en omstreken kende hij uit eigen waarneming en tijdens een veldtocht had hij in 1706 kennisgemaakt met de omgeving van Surabaya in het oosten van Java. Onderweg naar andere bestemmingen had hij Java's noordkust en Bantam bezocht. Voor alle overige gebieden, ook in de Indonesische archipel, was zijn kennis geheel afhankelijk van "papieren" die voor een belangrijk deel verschaft waren door een netwerk van merendeels voormalige functionarissen van de VOC.

De Leidse historicus Cees Fasseur heeft terloops wel eens opgemerkt dat Valentyns werk tot in de negentiende eeuw als naslagwerk gebruikt werd, waarbij het Fasseur ging om kennis over het destijdse Nederlands-Indië (Fasseur 20). Dat gebruik is nooit onderzocht. Dit artikel is bedoeld om hier voor de achttiende eeuw een beter inzicht in te krijgen. In dit artikel zal dit onderzoek alleen betrekking hebben op het gebruik van Valentyns werk binnen de VOC, waarbij zowel het gebruik door de centrale bestuursorganen in Nederland als door de etablissementen in Indië belicht zal worden. Het eerste zal gebeuren op basis van drie manuscripten die in het Nationaal Archief in Den Haag bewaard worden. In deze manuscripten is informatie over het octrooigebied van de VOC toegankelijk gemaakt en ze refereren geheel of voor een groot deel naar informatie uit Oud en Nieuw Oost-Indiën. Ze werden gebruikt door een vijftal bewindhebbers (directeuren) van de VOC die allen lid waren van het invloedrijke Haags Besogne, een commissie van de Heren XVII, het hoogste bestuurscollege van de VOC. Vervolgens zal een indruk worden gegeven van hoe Valentyns werk in diverse etablissementen ("kantoren") van de VOC in Azië gebruikt werd, op basis van correspondentie tussen deze instanties met het centrale bestuur van de VOC in Azië, de gouverneur-generaal en de Raad van Indië in Batavia

Dit onderzoek sluit aan bij de geschiedenis van kennis, een relatief nieuw type historisch onderzoek (van na 2000) dat vooral in het Duitse taalgebied tot ontwikkeling is gekomen, maar sindsdien ook internationaal gerecipieerd is. Hierbij wordt naast de genese van nieuwe kennis ook groot belang gehecht aan de circulatie van bestaande kennis en de media die daarbij een rol spelen. Dat laatste is ook in dit artikel ter sprake, waar het er onder meer om gaat vast te stellen op 
welke manier kennis uit Valentyns grote werk ontsloten is. Bij het begrip 'kennis' moet men overigens denken aan voorstellingen van de werkelijkheid waaraan door tijdgenoten geloof gehecht werd, wat niet betekent dat deze kennis ook in de $21^{\mathrm{e}}$ eeuw overtuigt (zie Philipp Sarasin voor een onderzoeksprogramma en Peter Burke voor een overzicht van het onderzoeksveld).

Het artikel is als volgt opgebouwd. Om de betekenis van Valentyns werk beter te kunnen begrijpen zal ik eerst kort iets zeggen over de context waarin Valentyns werk verscheen. ${ }^{1}$ Vervolgens zal ik het gebruik van Valentyns werk door bewindhebbers van de VOC in de Republiek onderzoeken, waarbij ik ook de werkwijze van het Haags Besogne zal toelichten waarvan de betreffende bewindhebbers lid waren (secties 2-3). Ten slotte zal ik proberen vast te stellen welk gebruik er in Indië van Oud en Nieuw Oost-Indiën werd gemaakt (sectie 4).

\section{Oud en Nieuw Oost-Indiën en het discours over Indië}

In de loop van de zeventiende eeuw had de VOC in Azië een uitgestrekt handelsrijk opgebouwd dat reikte van de Kaapkolonie in Zuid-Afrika tot Japan met daartussen gebieden in de Indonesische archipel, het Indiase schiereiland en Ceylon. Wie deze gebieden niet met eigen ogen had gezien, kon zich er omstreeks 1700 moeilijk een voorstelling van vormen, omdat er alleen een beperkte hoeveelheid geografische beschrijvingen beschikbaar was. In deze zin was er relatief veel publicitaire aandacht voor Japan, Taiwan, China, de Kaapkolonie, en de zuidelijke kustgebieden van het Indiase schiereiland en Ceylon. ${ }^{2}$ Voor elk van die gebieden bestonden chorografieën, een tekstsoort die haar oorsprong had in de klassieke oudheid (Strabo was het grote voorbeeld) en waarbij een bepaald land of een kleiner gebied zo gedetailleerd mogelijk beschreven werd (M. Friedrich 2003; Esser 2012; Verbaan 2013). Het kerngebied van dit handelsrijk - de Indonesische archipel - bleef in dit opzicht onderbelicht. Daarvoor was de lezer aan het begin van de achttiende eeuw aangewezen op reisverslagen, zoals die van Wouter Schouten (1676), Johan Nieuhof (1682), Nicolaus de Graaff (1701) en Cornelis de Bruin (1717), waarin de omzwervingen van de auteur de leidraad vormen en de feitelijke informatie over specifieke gebieden niet dezelfde omvang bereikt als in chorografieën die naar volledigheid streefden.

De directie van de VOC, de Heren XVII voelde in het laatste decennium van de zeventiende eeuw ook behoefte aan een beter overzicht en gaf daarom

${ }^{1}$ In dit artikel zal de oorspronkelijke spelling van Valentyns achternaam gevolgd worden. De spelling "Valentijn" dateert uit de negentiende eeuw. In afwijking van de stylesheet zal als volgt verwezen worden naar Valentyns werk: Romeins cijfer voor het boekdeel, Arabisch cijfer voor een sectie in het boekdeel en bladzijnummers voorafgegaan door " $p$ ".

2 Zie Lach en Van Kley (435-508) voor een vrij volledig overzicht van de betreffende publicaties. 
haar meest ervaren medewerker, advocaat Pieter van Dam (1621-1706), opdracht om een handboek samen te stellen dat in 1701 voltooid werd, de Beschryvinge van de Oostindische Compagnie (Van Dam). Weliswaar had de VOC-leiding in Amsterdam de beschikking over een zeer uitgebreid archief, maar dat was onvoldoende toegankelijk gemaakt voor gebruik. De archiefstukken bevonden zich in ongeordende toestand op verschillende locaties. Van Dams werk had de bedoeling om dit archief door een handboek te vervangen (S. Friedrich, "Caveat from the Archive"). Van Dams werk moest daarom de "information overload" (vgl. Blair 11) binnen het informatienetwerk van de VOC verminderen. Om te voorkomen dat concurrenten gevoelige informatie in handen zouden krijgen, bestond van dit handboek maar één handgeschreven exemplaar dat achter slot en grendel in het hoofdkwartier van de VOC, het Oost-Indisch Huis in Amsterdam, bewaard werd. Zodoende werd de informatie niet alleen aan het grote publiek onthouden, maar het is zelfs de vraag of Van Dams handboek beschikbaar was voor de leden van het Haags Besogne dat in dit artikel een belangrijke rol speelt, omdat dit gezelschap gewoonlijk in Den Haag vergaderde en daar dus niet direct kon beschikken over Van Dams Beschryvinge. Valentyns werk was in deze omstandigheden blijkens de manuscripten uit het bezit van vijf leden van het Besogne een goede vervanger, waarbij nog komt dat Valentyn in veel opzichten zelfs een meer gedetailleerde voorstelling gaf van de verschillende territoria van het VOC-imperium dan wat in Van Dams Beschryvinge te vinden was. Daarnaast zal ook blijken dat Oud en Nieuw Oost-Indiën voor functionarissen van de VOC in Indië een bruikbaar handboek was dat voor verschillende praktische kwesties geraadpleegd kon worden (sectie 4).

\section{Het Haags Besogne en Oud en Nieuw Oost-Indiën}

In de privé-archieven van vijf bewindhebbers van de VOC (vier daarvan vader en zoon) uit de achttiende eeuw die in het Nationaal Archief in Den Haag bewaard worden, bevinden zich gebonden verzamelingen met aantekeningen die geheel of gedeeltelijk gebaseerd zijn op Valentyns Oud en Nieuw Oost-Indiën. Deze vijf bewindhebbers waren zoals gebruikelijk afkomstig uit de bestuurlijke elite van provincies Holland en Zeeland (Gaastra, Geschiedenis van de VOC 31-34) en waren allen lid van het invloedrijke Haags Besogne, een commissie van het hoofdbestuur van de VOC, de Heren XVII. De leden van het Haags Besogne waren dus tegelijk lid van de Heren XVII. Hoewel ze daardoor sleutelposities bekleedden binnen het bestuur van de VOC, kende geen van hen het handelsterrein van de VOC uit eigen ervaring en waren ze bij de uitvoering van hun ambtelijke taken aangewezen op de in de Republiek beschikbare informatie.

De vijf bewindhebbers vertegenwoordigden drie van de zes kamers van de VOC. Samuel Radermacher (1693-1761) en zijn zoon Daniel Radermacher 
(1722-1803), die zijn vader als bewindhebber opvolgde, hadden namens de kamer Middelburg zitting. In hun archief is een gedeeltelijke samenvatting van de inhoud van delen van Valentyns Oud en Nieuw Oost-Indiën overgeleverd. ${ }^{3}$ In het archief van Jacob van Ghesel (1707-1773), die vanaf 1757 tot zijn dood namens de kamer Amsterdam zitting had, bevindt zich een tweede samenvatting van Oud en Nieuw Oost-Indiën, die grotendeels overeenkomt met die uit het Radermacher-archief. ${ }^{4}$ Het derde manuscript is afkomstig uit het archief van vader Adriaan van Vredenburch (1680-1759) en zoon Gerard van Vredenburch (1710-1784). Zij waren namens de kamer van Delft lid van de Heren XVII en het Besogne en ook hier heeft de zoon de vader in zijn functies opgevolgd. ${ }^{5}$ Dit derde manuscript verschilt van de twee eerder genoemde. Het is het tweede deel van een in lemma's verdeelde en alfabetisch gerangschikte tekst met informatie over de VOC en haar handelsgebied, van de letters L tot Z, die het midden houdt tussen een zakenindex en een encyclopedie. Het eerste deel (van A tot K) is niet overgeleverd. ${ }^{6}$ Ten slotte is er bij het Van Ghesel-archiefstuk nog een los blaadje met notities gevoegd met verwijzingen naar Valentyns werk dat ik hier onder als een apart document zal behandelen en voorlopig even buiten beschouwing zal laten. ${ }^{7} \mathrm{Bij}$ al deze documenten handelt het om "papieren instrumenten" (paper tools, vgl. Jardine 2017) die informatie beter toegankelijk moesten maken.

De vijf genoemde bewindhebbers hadden allen zitting in het Haags Besogne, dat jaarlijks van april tot september in Den Haag bijeenkwam. Deze commissie van (op papier) tien bewindhebbers was een buitengewoon invloedrijk subcomité van de Heren XVII. ${ }^{8}$ Ze was in 1653 opgericht als een commissie die door de VOC-leiding in Indië (de Gouverneur-Generaal en de Raad van Indië) met de retourvloot naar de Republiek jaarlijks verstuurde documentatie over de gang van zaken in de verschillende etablissementen van de VOC moest doorlezen. Op basis daarvan moest ze een conceptantwoord formuleren en een conceptbeleid uitstippelen dat uiteindelijk verwoord werd in de Patriase Missive van de Heren XVII, gericht aan de Gouverneur-Generaal en de Raad van Indië in Batavia. Daarnaast bepaalde het Besogne de hoeveelheid geld die door de afzonderlijke kamers van de VOC voor verzending naar Indië beschikbaar gesteld moest worden, schatte ze de winstgevendheid van Europese manufacturen en stelde ze de omvang van de vloot van de VOC vast.

${ }^{3}$ NNBW (Nieuw Nederlands Biografisch Woordenboek, http://resources.huygens.knaw.nl/retroboeken/nnbw/\#page $=0 \&$ accessor=accessor_index\&view=homePane) $2,1157,1152$; NL-HaNA, Radermacher, 1.10.69, inv. nr. 398.

${ }^{4}$ NL-HaNA, Ghesel, van, 1.10.31, inv. nr. 187 (NL-HaNa is de standaardafkorting van het Nederlands Nationaal Archief te Den Haag, zie Archivale Bronnen).

5 NNBW 7, 1294-1295; 1296.

6 NL-HaNA, VOC, 1.04.02, inv. nr. 13871. Het document is niet opgenomen in het Van Vredenburch-archief (NL-HaNA, Vredenburch, van, 3.20.61.01).

7 NL-HaNA, Ghesel, van, 1.10.31, inv. nr. 187.

8 Het volgende is gebaseerd op: Van Dam I, 1, 309-313; Gaastra, Bewind en Beleid 48-50; Gaastra, Geschiedenis van de VOC 150-155; Knaap 2012; Van Tilburg 2019. 
De meest tijdrovende taak was echter het doorlezen van de Generale Missive en de daarbij behorende Overgekomen Brieven en Papieren die door de VOCleiding met de retourvloot uit Batavia naar de Republiek waren verstuurd. De lectuur geschiedde onder grote tijdsdruk. Het Besogne begon onmiddellijk na aankomst van de in de lente gearriveerde retourvloot de documenten te lezen die met de vloot waren meegebracht. Bij de lectuur werd een vast systeem gevolgd. Beginnend met Amboina (de VOC-'provincie' Ambon en omliggende eilanden) en eindigend met de VOC-provincies op Java, werd het ene na het andere etablissement onder de loep genomen. Daarbij werd deze informatie gerelateerd aan het ongeveer drie jaar tevoren (want zo lang nam de communicatiecyclus in beslag) naar Batavia verzonden Patriase Missive van de Heren XVII om te controleren in hoeverre de destijds door de Heren XVII gegeven opdrachten waren uitgevoerd. In de praktijk kwam hiervan echter weinig terecht. Allereerst was de tijdsdruk groot. Geruime tijd voor het vertrek van de vloot in september moest de commissie al klaar zijn met de bestudering van de naar de Republiek verstuurde documenten, onder meer omdat bijtijds bepaald moest zijn met welke lading de schepen moesten uitvaren. Bovendien was de commissie nooit voltallig in haar samenstelling, waardoor het toch al omvangrijke werk over een kleinere groep verdeeld moest worden. Het gevolg hiervan was dat de commissieleden nauwelijks kennisnamen van de volledige documentatie en hun lectuur hoofdzakelijk beperkten tot de door de VOC-leiding in Batavia opgestelde Generale Missive. Daarbij was de interesse van het Besogne ook bijna uitsluitend gericht op de financiële en commerciële aspecten van de berichtgeving. De interesse voor gebeurtenissen die geen zakelijke belang hadden, bleef daardoor uiterst beperkt. Tegen de achtergrond van deze werkwijze zullen de commissieleden behoefte hebben gehad aan een referentiekader voor de documentatie die ze in hoog tempo moesten bestuderen. Bij gebrek aan eigen ervaring met het handelsterrein van de VOC - geen van vijf bewindhebbers die in dit artikel ter sprake zijn, was ooit in Indië geweest - waren ze aangewezen op overzichtelijke representaties. Dat Valentyns werk die rol vervuld kan hebben, valt af te leiden uit de correlatie tussen de hier boven beschreven gerichtheid op bedrijfsmatige kennis bij het Besogne en een soortgelijk accent in de documenten die in dit artikel ter sprake zijn.

\section{Oud en Nieuw Oost-Indiën beter toegankelijk gemaakt}

Als we voor het moment voorbijzien aan het losse blaadje met aantekeningen uit het Van Ghesel-archief, dan moesten de drie manuscripten uit de archieven van Middelburgse Radermachers, de Amsterdammer Van Ghesel en de Delftse Van Vredenburchs informatie uit Oud en Nieuw Oost-Indiën beter ontsluiten voor zijn gebruikers. 


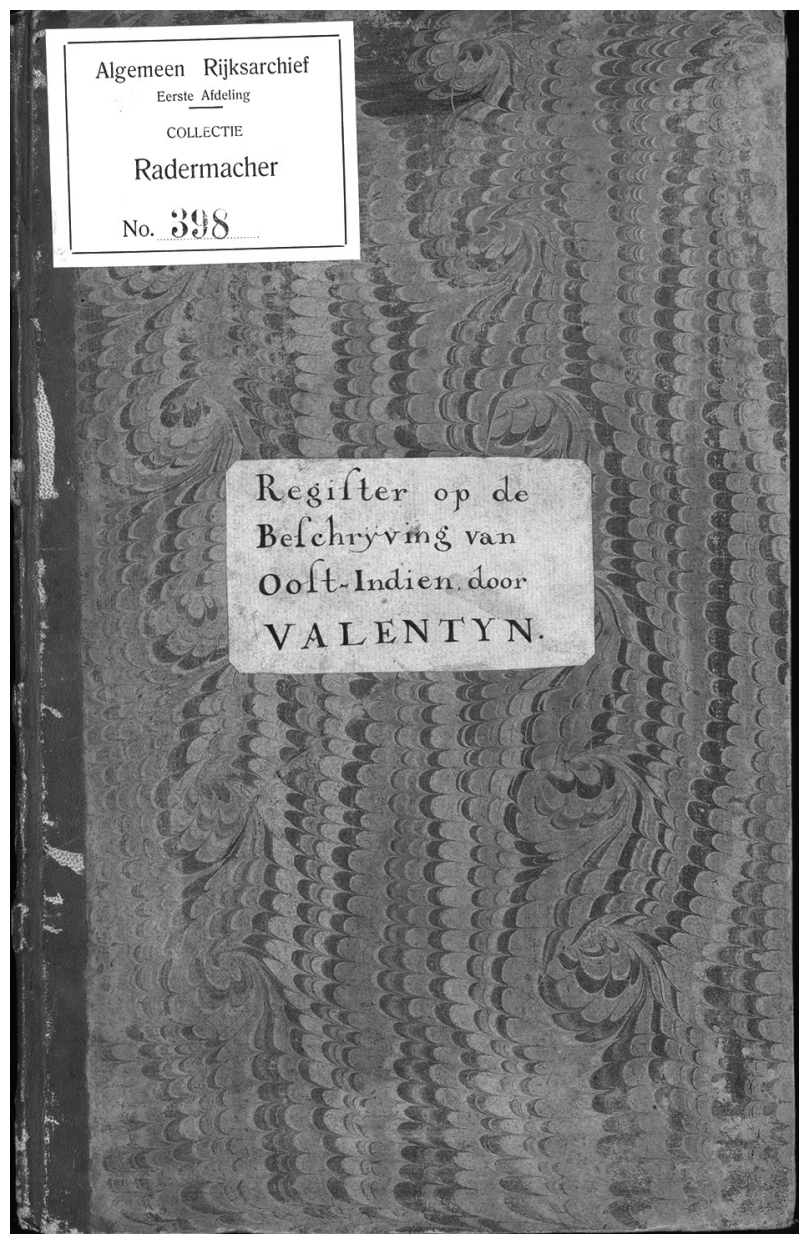

Fig. 1. Voorkant van het Radermacher-register; bron: NL-HaNA, Radermacher, 1.10.69, inv. nr. 398

De Radermacher-tekst (voortaan "Radermacher") en die uit het archief van Van Ghesel (voortaan "Van Ghesel") zijn vrijwel identiek. " "Radermacher" beslaat 88 onfolieerde bladzijden en draagt op het kaft de titel "Register op de Beschryving van Oost-Indien door Valentyn" (figuur 1). Volgens het Woordenboek der Nederlandsche Taal is een "register" een "[b]oek, inz. inschrijfboek, veelal van groot formaat", meer specifiek als inhoudsopgave. ${ }^{10}$ De tekst van "Radermacher" is gesteld in een zeer goed leesbaar netschrift.

9 NL-HaNA, Radermacher, 1.10.69, inv. nr. 398; NL-HaNA, Ghesel, van, 1.10.31, inv. nr. 187.

$10 \mathrm{http}: / /$ gtb.inl.nl/iWDB/search?actie $=$ article \&wdb=WNT\&id=M058340\&lemmodern=register\&domein $=0 \&$ conc $=$ true, geraadpleegd op 22 april 2021. 
De tekst van "Van Ghesel" is titelloos, en slordiger en dichter op elkaar geschreven, waardoor hij bij een vrijwel identieke inhoud maar 33 ongefolieerde bladzijden beslaat. De bladzij-indeling en volgorde van de samenvattingen van Valentyns landbeschrijvingen in "Van Ghesel" zijn hetzelfde als in Radermachers Register, ook in de zin dat de meeste marginalia en zelfs veel onderstrepingen in "Radermacher" evenzo voorkomen als in "Van Ghesel". De verhouding tussen de teksten (of de ene een afschrift is van de andere, dan wel beide van een niet overgeleverde derde tekst) valt niet te bepalen. Vanwege de geringe redactieverschillen tussen "Radermacher" en "Van Ghesel", zal ik in het vervolg van het betoog naar beide documenten verwijzen als de Registers (figuur 1).

De weergave van Valentyns tekst in de twee Registers varieert van een korte aanduiding van de inhoud van tekstdelen tot meer gedetailleerde samenvattingen. Ze geven de inhoud van Oud en Nieuw Oost-Indiën in dezelfde volgorde weer als in Valentyns boek, tot Valentyns beschrijving van "Groot Java" in het vierde boekdeel. Daarna zijn er afwijkingen in de volgorde van de tekstdelen, zonder dat te zeggen valt wat de functie van de meeste afwijkingen is. De secties over Kaap de Goede Hoop en Japan ontbreken. Bij Japan wordt in de marge verklaard dat de beschrijving van Japan door Engelbert Kaempfer (1651-1716) en het deel over Japan uit 1729 in de reeks met landbeschrijvingen die door Isaak Tirion (1705-1765) zijn uitgegeven (Kaempfer 1729; Salmon 1729), betere bronnen dan Valentyns boek zijn. De weglating van de Kaap de Goede Hoop wordt niet gemotiveerd, maar had vermoedelijk te maken met het geringe commerciële belang van de Kaapkolonie. Valentyns “Uyt- en T”Huys-Reyze” (IV, 3, pp. 95-166), een verslag van zijn scheepsreizen tussen de Republiek en Indië, blijft zelfs onvermeld. Andere secties worden alleen voor de volledigheid vermeld. Zo worden de honderden bladzijden die Valentyn had gewijd aan de natuurhistorie van Amboina (586 pp. tekst exclusief illustraties) en die alleen wetenschappelijk van belang waren, met enkele regels afgedaan. Taiwan, dat de VOC in de zeventiende eeuw verloren had, krijgt dezelfde behandeling. Daarentegen is er veel ruimte voor een samenvatting van Valentyns beschrijving van Ceylon die in Oud en Nieuw Oost-Indiën een iets kleinere omvang heeft (462 pp.) dan zijn natuurbeschrijving van Amboina (586 pp.).

Marginalia geven in het Register op sommige plaatsen commentaar bij de referenties naar Valentyns tekst. Zo wordt bij de verwijzing naar Valentyns weergave van het "Extract uit de Beschryving van den Staat en Gelegenheid van het Eyland Ceylon (...) door Ryklof van Goens (...)" (Valentyn V, 3, pp. 204-246) in de marge gewezen op de bijzondere waarde van dit document, waarin gouverneur Van Goens zijn kennis over Ceylon had samengevat: "Seer net, en weder op een andere wijse om beknopt Ceylon te leeren kennen". Van bijzonder interesse was ook Van Goens' "Consideratien over Ceylon" (Valentyn V, 3, pp. 148-151). In de marge is hier aangetekend: "dit ook te extraheren en bij p. 148 [van Valentyns beschrijving van Ceylon] de beschrijving der plaatsen na te sien en te confronte- 
ren en best die ordre te volgen". Dit lijkt een opdracht of voornemen te zijn om Van Goens' "Consideratien", zoals die bij Valentyn zijn afgedrukt en waarin een bestuurlijke evaluatie wordt gegeven van verschillende delen van Ceylon, geheel over te schrijven (te "extraheren") en vervolgens Van Goens beschrijving van de verschillende plaatsen op hun volledigheid te controleren ("na te sien") en te vergelijken ("confronteren") met andere informatie over de betreffende plaatsen, bijvoorbeeld zoals die elders in Valentyns beschrijving van Ceylon wordt gegeven. De Registers waren instrumenten die moest helpen om informatie in het werk van Valentyn snel te lokaliseren en door het combineren met andere informatie de mogelijkheid voor verdere bewerking te openen. ${ }^{11}$ Dit was ook nodig omdat zelfs een summiere inhoudsopgave in de verschillende delen van Oud en Nieuw Oost-Indiën ontbreekt. Weliswaar worden alle hoofdstukken in Valentyns boekwerk voorafgegaan door synopses, gaat de tekst vergezeld van marginalia en zijn de boekdelen voorzien van alfabetische indexen, maar een algemene inhoudsopgave of een per boekdeel ontbreekt.

In het archief van Van Ghesel is ook de Beknopte historie, van het Mogolsche keyzerryk en de zuydelyke aangrensende ryken overgeleverd. Het boekje is in 1758 door een anonieme auteur in Batavia gepubliceerd. ${ }^{12}$ Volgens het "Voor-berigt" was dit handzame boekwerkje gezuiverd van "vele grove misslagen" die men bij Valentyn zou vinden en aanmerkelijk geactualiseerd. Het diende voor Van Ghesel naar alle waarschijnlijkheid als aanvulling op Valentyns grote werk. Om op de hoogte te blijven van de politiek in het Mogolrijk was belangrijk voor de VOC omdat ze belangrijke vestigingen had op het Indiase subcontinent (Surat, de Malabar- en Coromandelkust, en Bengalen).

De Registers geven geen inzicht in de wijze waarop informatie uit Valentyns werk gecombineerd werd met informatie uit andere bronnen. Het derde document, afkomstig uit het bezit van de Delftste bewindhebbers, vader Adriaan van Vredenburch en zoon Gerard van Vredenburch, geeft hiervan wel een indruk. ${ }^{13}$ Dit document betreft een titelloze, alfabetisch geordende encyclopedie met allerlei informatie die betrekking had op de activiteiten van de VOC, haar handelsgebied, handelswaren en allerlei logistieke en organisatorische kwesties (voortaan "Encyclopedie"). Alleen het tweede deel, van de letter L (van "Lakenen") tot Z ("Zuidzeecompagnie"), is bewaard gebleven. Het ongefolieerde en gebonden archiefstuk beslaat 652 bladzijden waaronder veel onbeschreven bladen die bedoeld waren voor latere aanvullingen. Grofweg zijn er twee schrijfmomenten te onderscheiden: een in sepiakleurige inkt, toen de lemma's werden opgesteld en de bladzijruimte

11 Voor het begrip 'informatie' volg ik hier de definitie van Brendecke e.a. (16): "Unter 'Information' verstehen wir das, was an Repräsentationen der Welt in Hinsicht auf eine Aufgabe verfügbar ist".

12 NL-HaNA, Ghesel, van, 1.10.31, inv. nr. 188.

13 NL-HaNA, VOC, 1.04.02, inv. nr. 13871. 
werd ingedeeld. Bronverwijzingen ontbreken in deze schrijffase meestal. Latere aanvullingen zijn met donkere inkt en in een andere hand in de open ruimtes onder en tussen de bestaande tekst aangebracht, waarbij de toegevoegde informatie voorzien is van bladzijnummers wanneer verwezen wordt naar publicaties en gedateerde bronverwijzen naar archiefstukken. Bij deze aanvullingen gaat het vooral om gedateerde en chronologisch geordende verwijzingen naar het Haags Verbaal (dat wil zeggen de verslagen van de vergaderingen van het Haags Besogne, die in het Vredenburch-document worden afgekort als "HV") en bladzijverwijzingen naar Valentyns werk. Op het moment dat de "Encyclopedie") in de jaren 1750 werd bijgewerkt, was de meer recente informatie uit Valentyns werk nog maar enkele decennia oud. De laatste aanvullingen op basis van het Haags Verbaal dateren van 1755, wat erop wijst dat de tekst tijdens de ambtstermijn van vader Adriaan van Vredenburch tot stand is gekomen die in 1759 is overleden.

De lemma's, waarvan de trefwoorden in het handschrift onderstreept zijn, dekken een breed spectrum: handelsproducten ("Lakenen"), topografie ("Macassar"), bedrijfspolitiek ("Paapsgezinden"), procedures van het Haags Besogne ("Poincten van Beschryving"), uitrusting van schepen ("Stokvis"), personeel ("Vroedvrouw"), belangrijke personen ("Willem van Outhoorn") en financiën ("Wisselbrieven"). De omvang van de lemma's varieert sterk. Van de "Stokvis" volstond de informatie: "in droge vaten te doen". Voor topografische informatie, zoals bijvoorbeeld over "Persiën", waren acht beschreven bladzijden nodig, terwijl enkele lege bladzijden beschikbaar bleven voor aanvullingen. Zoals bij de inschrijvingen in de registers van Radermacher en Van Ghesel, kan de omvang van een lemma opgevat worden als indicatie van het belang van de daarin opgenomen informatie. De lemma's waarvoor informatie uit Oud en Nieuw Oost-Indiën gebruikt werd, boden zowel een samenvatting van de door Valentyn verzamelde chorografische informatie als verwijzingen naar bladzijden van zijn werk, zodat aanvullende informatie snel gevonden kon worden (figuur 2). In dat opzicht vervulde de "Encyclopedie" dezelfde functie als de Registers.

Valentyns werk is in de "Encyclopedie" vooral gebruikt voor chorografische informatie, dat wil zeggen een combinatie van geografische, historische gegevens, vermeldingen van gesloten verdragen en eventueel ook commercieel relevante informatie over handelsproducten en betaalmiddelen, zoals die onder meer in Valentyns beschrijving van Malakka (V, 1, p. 311) te vinden was. Door dat laatste had Oud en Nieuw Oost-Indiën op sommige plaatsen de eigenschappen van een ars mercatoria, een handboek voor de koopman (vgl. Hoock, Jeannin en Kaiser 1991). Deze handboeken hadden soms ook een geografische opzet en boden hun gebruikers de belangrijkste commerciële informatie voor een gebied of een stad. Een voorbeeld hiervan is The merchants mappe of commerce van Lewes Roberts (eerste druk, Londen 1638) die zijn lezer langs de belangrijkste "Cities and Townes of Traffique" in de wereld leidt, waaronder trouwens ook Malakka (Roberts 199-201). 
- Macader gelegin op ti Eytand Celebes, centyos Aeer befaamd, fororden groten handel, als friydbarken der hatie. legt om de ooft van Batavia 100 mälen. - Nocyelghheden miz devan Macalferuce gens have istravagante pritinder.

Expedice denwaars onién de majó fan Van

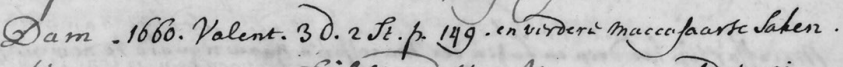
Krypuzrngrang, Fillstand Uan Wapenen; $260 . p \cdot 15 i$. Gedanten na Batavia. ats.

Notabe is diffractaot gesloten, en door de Coning geapprobt. 1667. Valint.unt

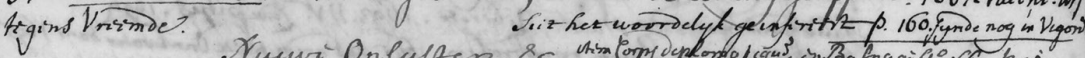

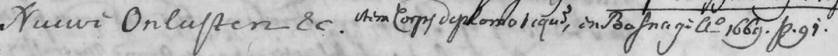
Atoedanc dat Ryt onder Y Kurvorsten wish virdect. Oncenigheden ondir dedelui" Encye Padias fuar onder Radalacca) Door haar mishandeld, veugten na Batural worden door huar ospecïpp, de laatste cen Oapper man, trivo in "ompt duenp: Nerdenterwydering met de Maeaffaris visoorsacht door haar Indolention en moor Geriyen. Een ummiffaris denuars on allesbyte leggen, doyte virqeefs.

comp! Bedienden, Foldyen, es Pasdouren.

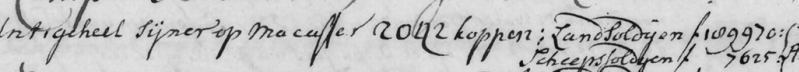

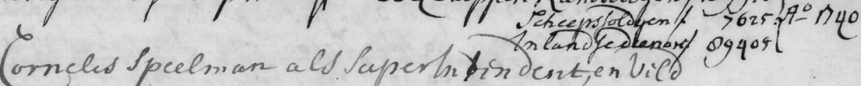

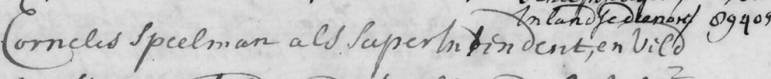

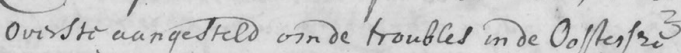

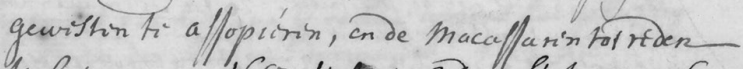

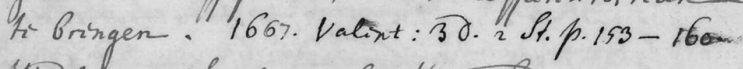

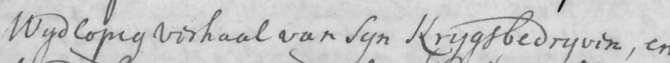

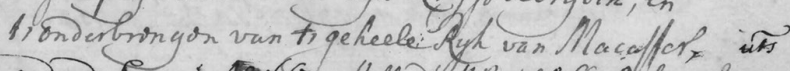

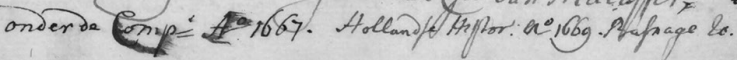

Fig. 2. Bladzijde met aantekeningen over Makassar uit de Vredenburch-"Encyclopedie"; bron: NL-HaNA, VOC, 1.04.02, inv. nr. 13871 
Naarmate een bepaalde plaats of gebied belangrijker was binnen het handelsnetwerk van de VOC, is de informatie in de "Encyclopedie" meer uitgebreid, waardoor Malabar, Malakka, Makassar, Perzië, Siam en Surat relatief veel aandacht krijgen. Bij de tweede ronde met inschrijvingen zijn alle beschrijvingen van gebieden die binnen het handelsnetwerk van de VOC van belang waren verder uitgebreid. De meer recente informatie bestaat uit gedateerde verwijzingen naar het Haags Verbaal die vooral als aanvulling bij referenties naar Valentyn zijn toegevoegd, wat erop wijst dat Oud en Nieuw Oost-Indiën in de ogen van de samenstellers van de "Encyclopedie" de chorografische basis bevatte, die met behulp van het Haags Verbaal geactualiseerd is. In enkele gevallen wordt ook verwezen naar afbeeldingen in Valentyns werk, zoals in het lemma over "Macassar" waar verwezen wordt naar de "nette aftekening" van het fort Rotterdam, waar zich de bestuurszetel van het "gewest" Makassar bevond (zie figuur 3).

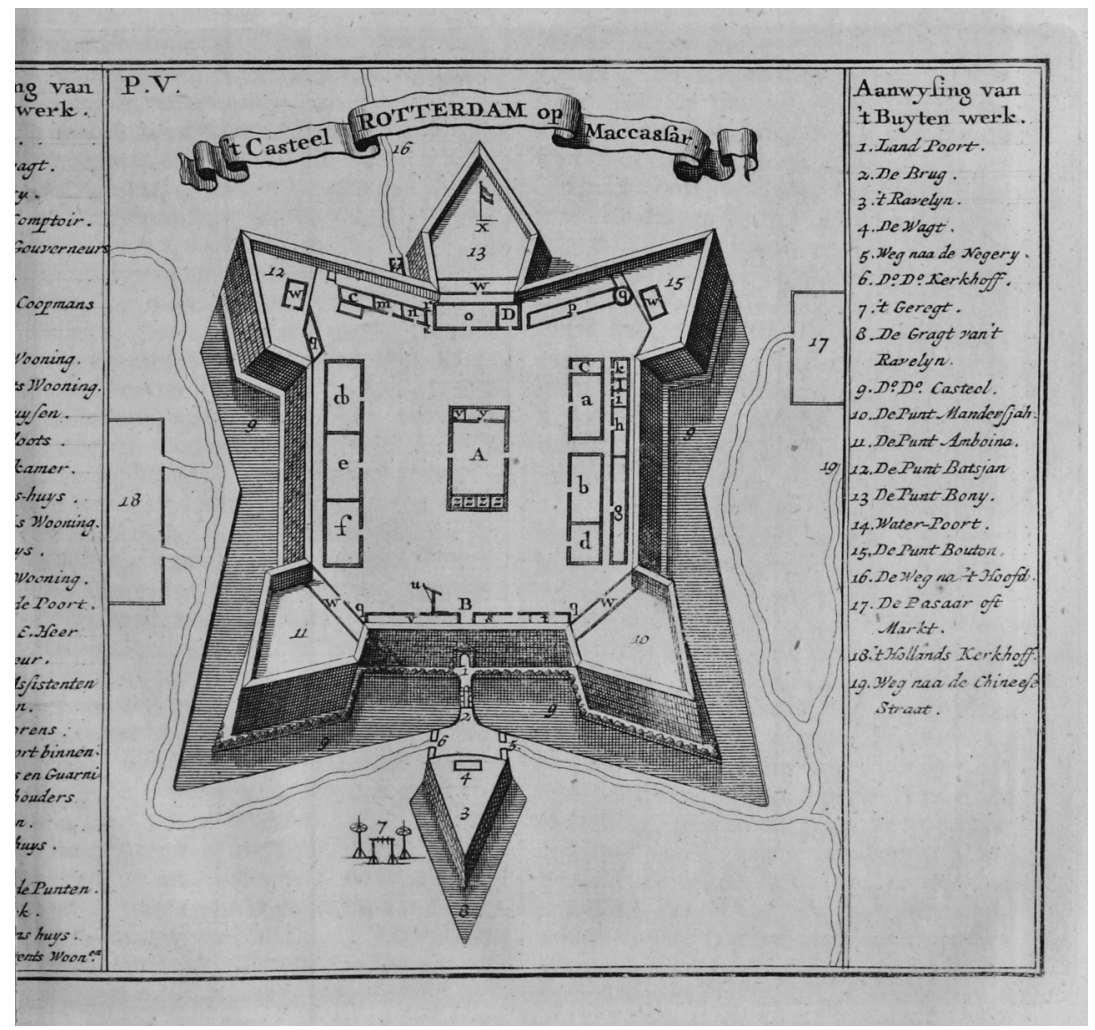

Fig. 3. Plattegrond van het fort Rotterdam in Makassar; bron: Valentyn III, 2, tegenover p. 136

De "Encyclopedie" van de Vredenburchs was een instrument waarmee summiere kennis over verschillende aspecten van het bedrijf en het handelsgebied 
van de VOC voor onmiddellijk gebruik toegankelijk was gemaakt, maar waarbij de gebruiker voor meer volledige informatie werd verwezen naar Oud en Nieuw Oost-Indiën of het Haags Verbaal. In de honderden bladzijden met aantekeningen wordt alleen sporadisch verwezen naar andere publicaties. ${ }^{14}$ Omdat Valentyn het hele handelsgebied van de VOC beschreven had en daarbij bovendien geput had uit bestaande publicaties, had zijn werk weinig concurrentie te duchten van publicaties die alleen een deel van het handelsgebied beschreven.

Naast de drie teksten die hier boven ter sprake waren, is er bij het register van Van Ghesel nog een los, aan de randen gescheurd en bevlekt blad met aantekeningen gevoegd met referenties naar de eerste drie boekdelen van Oud en Nieuw Oost-Indië. Dit velletje is tot nu toe in de bespreking terzijde gelaten. De aantekeningen zijn blijkens het slordige en slecht leesbare schrift voor eigen gebruik gemaakt. Uit deel I van Oud en Nieuw Oost-Indiën is informatie genoteerd over de Spaanse aanwezigheid en handel in de Filippijnen, de Nederlandse veroveringen in Azië van 1605 tot 1669 en informatie over het eiland Ternate in de Molukken (handel, bevolkingsstatistieken en Nederlandse belangen ter plaatse), uit deel II over de productie van katjeputolie op Ambon en uit deel III is genoteerd op welke bladzijde een lijst met "vissenallerlysoorten" (vissen allerlei soorten) begint. De meeste informatie is ook te vinden in het register van Van Ghesel en dus zijn de notities vermoedelijk op basis hiervan en niet van Valentyns werk gemaakt, met uitzondering van een verwijzing naar Valentyns lijst met kleurrijke tropische vissen in het derde boekdeel. Deze notitie zal zonder tussenkomst van het register uitgevoerd zijn, omdat in het register geen verwijzing naar de vissen was opgenomen.

\section{Het gebruik van Oud en Nieuw Oost-Indiën in Indië}

De volgende vraag betreft het gebruik van Valentyns werk in Indië. Hiervoor biedt de correspondentie van de etablissementen met de regering in Batavia

14 In verband met de volgende onderwerpen wordt in de "Encyclopedie" ook naar andere bronnen dan Valentyn verwezen: Malabar aan de westkust van India (Philippus Baldaeus, Naauwkeurige beschryvinge van Malabar en Choromandel, 1672); Malakka (Jan Huygen van Linschoten, Itinerario, voyage ofte schipvaert naer Oost- ofte Portugaels Indien, 1596; Isaac Commelin, Begin ende voortgangh van de Vereenighde Nederlantsche Geoctroyeerde Oost-Indische Compagnie, 1646); Manado (Daniêf Havart, Op-en ondergang van Cormandel, 1693; William Dampier, A New Voyage Around the World, 1697); de Mogol-dynastie (François Bernier, Histoire de la dernière révolution des états du Grand Mogol, 1670-1671); Negapatnam aan de oostkust van India (Daniel Havart, Open ondergang van Cormandel, 1693; Philippus Baldaeus, Naauwkeurige beschryvinge van Malabar en Choromandel, 1672); geruchten over een huwelijk tussen de koning van Engeland met een Portugese prinses (Lieuwe van Aitzema, Saken van staet en oorlogh, 1655-1671); de Engelse factorij in Surat aan de noordwestkust van India (Thomas Salmon, Hedendaagsche historie of Tegenwoordige staat van alle volkeren, IIIde deel, 1731). 
inzicht. De verschillende vestigingen van de VOC in Azië waren verplicht geregeld verslag uit te brengen aan de gouverneur-generaal en de Raad van Indië (de "Hoge Regering") in Batavia. Deze verslagen werden in kopie-vorm als bijlage van de Generale Missive meegestuurd naar de Republiek (Gaastra, De geschiedenis van de VOC 66) en zijn thans deel van het VOC-archief in het Nationaal Archief in Den Haag.

Sinds mei 2021 is het technisch mogelijk geworden om het VOC-archief in Den Haag (1,5 miljoen bladzijden gedigitaliseerde tekst) te doorzoeken met behulp van het transscriptieplatform Transkribus dat is ontwikkeld voor het lezen van gedigitaliseerde, handgeschreven tekst (vgl. Keijser). Dit opent de mogelijkheid om een indruk te krijgen van de circulatie van Valentyns werk in Indië. Mijn zoektocht naar vermeldingen van Valentyns werk heeft een tiental treffers opgeleverd in stukken die allemaal behoren tot de reeks "Kopie-missiven en -rapporten ingekomen bij gouverneur-generaal en raden van de kantoren in Indië" die oorspronkelijk bewaard werden bij de Kamer Zeeland in Middelburg, maar die nu onderdeel zijn van het VOC-archief in Den Haag. ${ }^{15}$ Aangezien de treffers beperkt zijn tot deze sectie van het archief, heb ik de indruk dat Transskribus nog niet goed werkt voor het gehele VOC-archief. ${ }^{16}$ We mogen daarom aannemen dat het archief veel meer gebruikssporen van Oud en Nieuw Oost-Indiën bevat dan het tiental vermeldingen dat ik kon opsporen. De treffers vormen daarom niet meer dan een kleine steekproef van de vermeldingen van Valentyns werk in Indische bestanden.

De treffers zijn afkomstig uit correspondentie van de kantoren Ceylon, Ternate, Makassar, Banda en Honimoa (Saparua, Amboina), alsook uit de bestanden van de Raad van Justitie in Batavia. Wat Honimoa (Fort Duurstede in Saparua) betreft, is het vermeldenswaard dat het hier gaat om een lager bestuurlijk niveau. Fort Duurstede was het centrum van een bestuurlijk district binnen de 'provincie' Amboina, waarvan Ambon-stad de hoofdplaats was.

De vroegste vermelding van Valentyns werk komt voor in een "Memorie van Overgave" uit 1740, een document dat een aftredend hoofd van een VOCvestiging in Indië opstelde voor zijn opvolger om deze op de hoogte te stellen van de toestand van het kantoor. Hierin verwijst de aftredende gouverneur van Ceylon en latere gouverneur-generaal baron Van Imhoff naar aanleiding van een

15 1.04.02 Inventaris van het archief van de Verenigde Oost-Indische Compagnie (VOC), 1602-1795 (1811). Versie: 12-05-2021, 74.

16 De treffers hebben allemaal betrekking op een serie Kopie-ingekomen stukken bij gouverneur-generaal en raden uit de vestigingen in Indië in het archief van de kamer Zeeland (NL-HaNA, VOC, 1.04.02, inv. nrs. 7658-9179). De bestanden uit deze reeks komen overeen met die in het "Batavia's ingekomen brievenboek" en met de serie van de overgekomen brieven en papieren uit Indië in het archief van de kamer Amsterdam. Vanwege deze triplicering had men ook treffers in de twee andere series mogen verwachten, wat echter niet het geval bleek te zijn tijdens mijn eind mei 2021 uitgevoerde zoektocht. Dit wijst erop dat Transskribus toen nog niet goed werkte. 
door zijn voorganger Joan Maetsuycker opgestelde Memorie naar de publicatie ervan in Valentyns werk. Daarbij kenschetst hij Valentyn en zijn werk als de van de waarheid afwijkende ("devieerenden") maar niettemin "seer schadelijken Valentijn in dat bekende oud en nieuw Oost Indiën". ${ }^{17}$ Naar de betekenis van de eerste woorden in de laatste de bewering kan men gissen, maar het zou kunnen betekenen dat Valentyn te veel uit de school geklapt had en naast van de waarheid afwijkende informatie ook correcte inlichtingen over het octrooigebied gepubliceerd had, waarvan concurrenten, zoals bijvoorbeeld de Engelse East India Company, hun voordeel mee hebben kunnen doen. In elk geval gaat Imhoff er in 1740 van uit dat Valentyns werk veertien jaar na de publicatie van het laatste deel in 1726 algemene bekendheid geniet, wat ook een aanduiding is van de mate waarin het schadelijk zou kunnen zijn.

Ook bij de andere verwijzingen naar Valentyns werk die ik gevonden heb, gaat het steeds om concrete, lokaal relevante informatie. In twee gevallen gaat het om cartografische informatie. Zo had men in 1769 op het eiland Honimoa (Saparua, Amboina), behoefte aan een kaart van een landstreek op het eiland in verband met een dispuut tussen twee inheemse hoofden. De enige tijd tevoren vervaardigde kaart bleek onbruikbaar. Degene die hem gemaakt had, had in plaats van een kaart van de bedoelde landstreek een kaart van Honimoa (dus van het gehele eiland) uit Valentyns werk gekopieerd. ${ }^{18}$ Een kaart uit Valentyns werk werd in 1790 ook door de gouverneur en raad van Banda gebruikt in een grensdispuut met het de VOC-provincie Amboina, waarbij Banda zich beriep op een afbakening die te vinden was op een kaart in Valentyns werk. ${ }^{19}$ Ook in de overige gevallen gaat het om specifieke informatie. Op Ternate (Molukken) werden ambtelijke voorschriften voor functionarissen aan Valentyns werk ontleend, omdat het archief op Ternate een rommeltje was. ${ }^{20}$ Daarnaast kregen VOC-missies uit Ternate en Makassar, die in de periode 1770-1786 buiten het monopoliegebied van de VOC groeiende kruidnagelplanten moesten uitroeien ("extirperen") afbeeldingen van deze planten mee die waren gekopieerd uit Valentyns werk. ${ }^{21}$ De expedities uit Makassar werden bovendien voorzien van een kopie van een contract met de heerser van Buton uit Valentyns werk, zodat ze hun activiteiten op het territorium van Buton indien nodig konden verantwoorden. Bij het gebruik van Valentyns werk door de Raad van Justitie in Batavia Valentyns werk ging het om demo-

17 NL-HaNA, VOC, 1.04.02, inv. nr. 8979, 12 maart 1740, fol. 310.

18 Honimoa (Saparua, Amboina; NL-HaNA, VOC, 1.04.02, inv. nr. 7932, 30 november 1769 , fol. 987).

19 Banda (NL-HaNA, VOC, 1.04.02, inv. nr. 7946, 8 juni 1790, fol. 21).

20 Ternate, Molukken (NL-HaNA, VOC, 1.04.02, inv. nr. 8161, 10 juli 1780, fol. 332-333; inv. nr. 8143, 5 augustus 1781, fol. 5)

21 Makassar, Sulawesi (NL-HaNA, VOC, 1.04.02, inv. nr. 7948, 5 juni 1770, fol. 254-255; inv. nr. 8252, 16 november 1784, fol. 95; inv. Nr, 8263, 31 [sic] oktober 1786, fol. 2); Ternate, Molukken (NL-HaNA, VOC, 1.04.02, inv. nr. 8154, 7 september 1772, fol. 13). 
grafische informatie. De Raad wilde in 1755 te weten komen hoeveel Chinezen in Batavia gewoond hadden op het moment dat Valentyn hierover informatie verzamelde. ${ }^{22}$ Uit deze voorbeelden wordt duidelijk dat Valentyns werk anders dan Van Imhoff beweerde binnen het ambtelijke circuit van de VOC gezien werd als een bron van betrouwbare informatie en in meerdere gevallen zelfs gebruikt werd alsof het om een intern beleidsdocument ging.

\section{Slotbespreking}

De "Encyclopedie" en de twee registers maken duidelijk dat Oud en Nieuw OostIndiën door de betrokken bewindhebbers werd opgevat als een belangrijke bron van informatie over gebieden in Indië die voor de VOC van belang waren. Tegelijkertijd werd Valentyns werk in Indië gebruikt als een handboek waarin allerlei praktische informatie gevonden kon worden. Het was in de vroegmoderne tijd niet ongebruikelijk dat gepubliceerde chorografieën (zoals het boek van Valentyn) werden gebruikt als grondslag voor bestuurlijk handelen (vgl. S. Friedrich, "“Zu nothdürfftiger information"”). De overtuiging had zich gevestigd dat bestuur gebaseerd moest zijn op betrouwbare informatie en het hinderde daarbij niet dat Valentyns werk grotendeels een compilatiewerk was, samengesteld uit de observaties van meerdere personen. Er was in zo'n geval sprake van "compositorische autopsie" waaraan ook epistemische geldigheid werd toegeschreven (M. Friedrich 318). Als het gaat om de aard van de informatie die voor de bewindhebbers relevant was, dan lijkt Valentyns werk vooral basisinformatie over het handelsgebied van de VOC met een langere houdbaarheidsduur verschaft te hebben (vgl. S. Friedrich, “'Zu nothdürfftiger information"” 302). De prijzen van handelsproducten fluctueren, maar het eerder genoemde Fort Rotterdam in Makassar bleef hetzelfde.

Het was trouwens niet voor het eerst dat er binnen een vroegmoderne handelsonderneming gebruik gemaakt werd van voor een algemeen publiek gepubliceerd boek. Dit was al eerder gebeurd met het Reys-gheschrift (1595) en de Itinerario (1596) van Jan Huygen van Linschoten (ca. 1563-1611) die tot in de eerste helft van de zeventiende eeuw gebruikt werden door de Nederlandse voorcompagnieën (de voorgangers van de VOC), de VOC en de Engelse East India Company voor tochten naar Azië (Parmentier 164; Delmas 101-102, 113-115, 117-120). Het Itinerario werd bovendien in de tweede helft van de zeventiende eeuw voor korte tijd door de VOC-leiding in de Kaapkolonie gebruikt bij het organiseren van onderzoekstochten in het binnenland van Zuid-Afrika (Huigen 23-59).

22 Batavia, kopie-criminele en -civiele processtukken van de Raad van Justitie in Batavia (NL-HaNA, VOC, 1.04.02, inv. nr. 9448, 1755, ongefol.). De bevolkingsstatistieken waren door de "Chinezenmoord" van 1740 namelijk drastisch veranderd. 
Wat uit de registers en de "Encyclopedie" ook duidelijk wordt, is dat de kennisinteresse van de bewindhebbers selectief was, want ze beperkte zich tot kennis over Indië die economisch relevant was. De bewindhebbers hadden behoefte aan een overzicht van het operatiegebied in Azië en de producten die daar vandaan kwamen. Vandaar dat bijvoorbeeld Valentyns natuurbeschrijvingen in de registers niet werden samengevat en dat wat hij over Kaap de Goede Hoop schreef evenmin werd weergegeven. Dit komt overeen met de constatering van Susanne Friedrich dat de bewindhebbers met een vernauwde "economische blik" naar Indië keken (S. Friedrich, "Unter Einsatz aller Sinne" 387-390; zie ook Van Tilburg 60-61). Dat Jacob van Ghesel op een los blad papier een aantekening maakte over Valentyns lijst met tropische vissen, vormt hierop een zeldzame uitzondering. Deze notitie had zeer zeker niet te maken met zijn professionele interesses.

Oud en Nieuw Oost-Indiën vervulde voor de bewindhebbers tot op grote hoogte dezelfde functie als de beschrijving van het overzicht van het handelsgebied van de VOC dat door Pieter van Dam in opdracht van de Heren XVII in 1701 was voltooid. Van Dam had onafhankelijk van Valentyn zelfs voor een deel dezelfde bronnen gebruikt (Stapel xi). Weliswaar bood Van Dam meer informatie over de bedrijfsmatige en bestuurlijke kant van de VOC ("Boeken" I en III van Van Dams Beschryvinge), maar Valentyn bood over het algemeen meer omvangrijke en meer actuele, chorografische informatie dan wat Van Dam hierover in het tweede Boek van zijn werk te melden had. Oud en Nieuw Oost-Indiën was bovendien voorzien van kaarten en illustraties, zodat het aan de gebruiker een rijker beeld verschafte. Zodoende bood Oud en Nieuw Oost-Indiën aan de bewindhebbers een referentiekader bij het haastig doornemen van de Generale Missive en de Overgekomen Brieven en Papieren. De indeling van Valentyns werk correleerde zelfs enigszins met de werkwijze van het Besogne (zie sectie 2). Zoals Valentyn zijn beschrijving had ingericht als een reeks chorografieën, zo volgden de bewindhebbers in hun vergadering ook een geografisch gestructureerd scenario bij de bespreking van de verschillende etablissementen.

Op de kantoren in Azië lijkt Valentyns werk vooral gebruikt te zijn voor lokaal relevante informatie. Daarbij ging het om afbeeldingen van kruidnagelplanten, kaarten, contracten met inheemse heersers, ambtelijke voorschriften en memories van overgave. Blijkens de uitspraak van de aftredende gouverneur van Ceylon genoot Oud en Nieuw Oost-Indiën in 1740 al bekendheid binnen het VOC-netwerk. Van belang is ook dat het werk beschikbaar was op een aan de hoofdplaats Ambon ondergeschikte vestiging op het eiland Honimoa, wat wijst op een verspreiding in Indië die verder reikte dan de hoofdvestigingen.

Valentyns werk had als bron van informatie over het octrooigebied van de VOC een belangrijk voordeel: er bestonden honderden, nagenoeg identieke, vijfdelige sets van. Er kon zodoende voor de bewindhebbers en functionarissen in Indië die van Oud en Nieuw Oost-Indiën gebruik maakten een gedeeld refe- 
rentiekader ontstaan (vgl. Eisenstein) ${ }^{23}$ Voor de lezers in de Republiek kan Oud en Nieuw Oost-Indiën zelfs hebben gefunctioneerd als een papieren interface van Indië.

\section{Bibliografie}

\section{Databasissen}

NNBW. Nieuw Nederlandsch Biografisch Woordenboek. Online: http://resources.huygens.knaw.nl/ retroboeken/nnbw/\#page $=0 \&$ accessor=accessor_index\&view $=$ homePane.

WNT. Woordenboek der Nederlandsche Taal Online: $\bar{h}$ ttps://gtb.ivdnt.org/search/.

Zoeken in transcripties (Nationaal Archief, Den Haag). Online: https://zoekintranscripties.nl.

\section{Onuitgegeven archiefbronnen}

\section{Nationaal Archief, Den Haag}

Collectie Van Ghesel, nummer toegang 1.10.31, inventarisnummers 187, 188.

Collectie Radermacher, nummer toegang 1.10.69, inventarisnummer 398.

Verenigde Oostindische Compagnie (VOC), nummer toegang 1.04.02, inventarisnummers 7932, 7946, 7948, 8143, 8154, 8161, 8252, 8263, 8979, 9449, 13871.

\section{Publicaties}

1.04.02 Inventaris van het archief van de Verenigde Oost-Indische Compagnie (VOC), 1602-1795 (1811). Versie: 12-05-2021, https://www.nationaalarchief.nl/onderzoeken/archief/1.04.02. Geraadpleegd 14 juni 2021.

Beknopte historie, van het Mogolsche keyzerryk en de zuydelyke aangrensende ryken. Te Batavia: Gedrukt in de Casteels Druckery, door C. Renhard, 1758.

Blair, Ann. Too Much to Know: Managing Scholarly Information Before the Modern Age. Yale University Press, 2010.

Brendecke, Arndt, et al. "Information als Kategorie historischer Forschung. Heuristik, Etymologie und Abgrenzung vom Wissensbegriff”. Information in der Frühen Neuzeit. Status, Bestände, Strategien, geredigeerd door Arndt Brendecke et al. Lit, 2008, pp. 11-44.

Burke, Peter. What is the History of Knowledge? John Wiley \& Sons, 2015.

De Bruin, Cornelis. Reizen over Moskovie, door Persie en Indie verrijkt met 300 kunstplaaten door den auteur zelf na 't leven afgeteekend. T'Amsteldam: by Rudolph en Gerard Wetstein, 1717.

23 Elizabeth Eisenstein heeft er in The printing press as an agent of change op gewezen dat de introductie van de drukpers heeft geleid tot standaardisering van kennis. Ze is hierop bekritiseerd, als zou ze voorbijgezien hebben aan de variaties die tot aan de negentiende eeuw in drukwerk gevonden werden (onder meer door David McKitterick 99-111 en Adrian Johns 10-11). Deze critici zien echter voorbij aan de belangrijke opmerking op p. 81 van The printing press dat de producten van de drukpers bij alle variaties "sufficiently uniform" waren om aan standaardisering van kennis een belangrijke rol te kunnen toekennen. 
Delmas, Adrien. Les voyages de l'écrit: Culture écrite et expansion européenne à l'époque moderne; essais sur la Compagnie hollandaise des Indes orientales. Champion, 2013.

Eisenstein, Elizabeth. The printing press as an agent of change: communications and cultural transformations in early modern Europe, 2 vols. Cambridge University Press, 1979.

Esser, Raingard. The Politics of Memory. The Writing of Partition in the Seventeenth-Century Low Countries. Brill, 2012.

Fasseur, Cees. De Indologen: ambtenaren voor de Oost 1825-1950. Bert Bakker, 1993.

Friedrich, Markus. "Chorographica als Wissenskompilationen: Probleme und Charakteristika". Sammeln, Ordnen, Veranschaulichen: Zur Wissenskompilatorik in der Frühen Neuzeit, geredigeerd door Frank Büttner et al. Lit, 2003, pp. 83-110.

Friedrich, Susanne. "Caveat from the Archive: Pieter van Dam's Beschryvinge van de Oostindische Compagnie and Crisis Management". Journal for the History of Knowledge, vol. 1, no. 1, 2020, pp. 1-14. DOI: http://doi.org/10.5334/jhk.15.

---. "Unter Einsatz aller Sinne: Zum ökonomischen Blick und dem Sammeln von Wissen in der Frühphase der niederländischen Ostindienkompanie (1602-ca. 1650)". Historische Anthropologie, vol. 28, no. 3, 2020, pp. 379-398.

---. “'Zu nothdürfftiger information': Herrschaftlich veranlasste Landeserfassungen des 16. und 17. Jahrhunderts im Alten Reich". Information in der Frühen Neuzeit: Status, Bestände, Strategien, uitgegeven door Arndt Brendecke et al. Lit, 2008, pp. 301-334.

Gaastra, Femme Simon. Bewind en Beleid bij de VOC: De financiële politiek van de bewindhebbers, 1672-1702. De Walburg Pers, 1989.

---. Geschiedenis van de VOC: Opkomst, bloei en ondergang. De Walburg Pers, 2013.

Graaff, Nicolaus. Oost-Indise spiegel door Nicolaus de Graaff. Hoorn, Feyken Ryp, 1701.

Hoock, Jochen, et al. redacteur. Ars mercatoria: Handbücher und Traktate für den Gebrauch des Kaufmanns, 1470-1820. Schöningh, 1991.

Huigen, Siegfried. De weg naar Monomotapa. Amsterdam University Press, 1996.

Jardine, Boris. "State of the field: Paper tools". Studies in History and Philosophy of Science. Part A, vol. 64, 2017, pp. 53-63.

Johns, Adrian. The nature of the book: Print and knowledge in the making. University of Chicago Press, 1998.

Kaempfer, Engelbert. De beschryving van Japan, behelsende een verhaal van den ouden en tegenwoordigen staat en regeering van dat ryk. 's Gravenhage, by P. Gosse en J. Neaulme; 't Amsterdam, Balthasar Lakemann, 1729.

Keijser, Liesbeth. Projectplan. De ijsberg zichtbaar maken. Nationaal Archief, https://www.nationaalarchief.nl/handschriftherkenning/projectplan-de-ijsberg-zichtbaar-maken. Geraadpleegd 14 juni 2021.

Knaap, Gerrit. "Communication, information, and power in the Dutch colonial empire". Information and Power in History: Towards a Global Approach, geredigeerd door Ida Nijenhuis et al. Routledge, 2020, pp. 122-137.

Lach, Donald F., en Edwin J. van Kley. Asia in the Making of Europe, vol. III: A Century of Advance, vol. 3: Southeast Asia. Book One: Trade, Missions, Literature. University of Chicago Press, 1993.

McKitterick, David. Print, manuscript and the search for order, 1450-1830. Cambridge University Press, 2003.

Nieuhof, Johan. Zee- en Lant-Reise door verscheide Gewesten van Oostindien, behelzende veele zeldzaame en wonderlijke voorvallen en geschiedenissen. Amsterdam: de Weduwe van Jacob van Meurs, 1682. 
Parmentier, Jan. "In het kielzog van Van Linschoten. Het Itinerario en het Reys-gheschrift in de praktijk Tijdens de 16de en 17de eeuw". 'Souffrir Pour Parvenir'. De Wereld Van Jan Huygen Van Linschoten 1562-1611, geredigeerd door R. van Gelder et al. Arcadia, 1998, pp. 152-167.

Roberts, Lewis. The merchants mappe of commerce. London, Printed by R.O. for Ralph Mabb, 1638.

Salmon, Thomas. Hedendaegsche Historie, of Tegenwoordige Staet van alle Volkeren; In opzigte hunner Landsgelegenheit, Personen, Klederen, Zeden, Wetten, Gewoontes (...), vol. I: Behelzende de Tegenwoordige Staet der Keizerryken China en Japan, als mede van de Ladrones, Filippynsche en Molukkische Eilanden en van Makassar, vertaling M. van Goch. Amsterdam, Isaak Tirion, 1729.

Sarasin, Philipp. "Was ist Wissensgeschichte?". Internationales Archiv für Sozialgeschichte der deutschen Literatur, vol. 36, no. 1, 2011, pp. 159-172.

Schouten, Wouter. Oost-Indische voyagie; vervattende veel voorname voorvallen en ongemeene vreemde geschiedenissen, bloedige zee- en landtgevechten tegen de Portugeesen en Makassaren. T'Amsterdam, Jacob Meurs en Johannes van Someren, 1676.

Tilburg, Richard van. Company of Missives: the Epistemic Potential of Colonial Records in the Dutch East India Company (1727-1770). MA Diss. Universiteit Leiden, 2019.

Valentyn, François. Oud en Nieuw Oost-Indiën. Vervattende Een Naaukeurige en Uitvoerige Verhandelinge van Nederlands Mogentheyd in die Gewesten, 5 vols. Dordrecht, Johannes van Braam, en Amsterdam, Gerard onder de Linden, 1724-1726.

Van Dam, Pieter. Beschryvinge van de Oostindische Compagnie, geredigeerd door Frederik W. Stapel en C.W.Th. Baron van Bozelaer. 7 vols. Nijhoff, 1927-1954.

Verbaan, Eddy. De woonplaats van de faam. Grondslagen van de stadsbeschrijving in de zeventiende-eeuwse Republiek. Verloren, 2013. 